\title{
FORMULASI DAN UJI EFEKTIVITAS ANTIOKSIDAN SEDIAAN MASKER PEEL-OFF EKSTRAK ETANOL DAUN SESEWANUA (Cleodendron squamatum Vahl.)
}

\author{
Ferrna F. Rompis ${ }^{1)}$, Paulina V.Y Yamlean ${ }^{1)}$, Widya Astuty Lolo ${ }^{1)}$ \\ Program Studi Farmasi FMIPA UNSRAT Manado, 95115
}

\begin{abstract}
Sesewanua leaves (Cleodendron squamatum Vahl.) contain alkaloids and flavonoids which are efficacious as antioxidants. This study aimed to fomulate, evaluate, and test the effectiveness of antioxidants in the form of peel-off mask of ethanol extract from the Sesewanua leaves. This study used descriptive-analytic method with the treatment of variations in concentrations of PVA $12 \%, 14 \%$ and $16 \%$, respectively. Physical evaluation of preparations included organoleptic observation, homogeneity test, $p H$ test, scattering power test, drying time test, and cycling test, all tests were carried out before and after the cycling test. The results showed that all preparations met the requirements of physical evaluation before the cycling test while after the cycling test only preparations with $12 \%$ PVA concentrations met the requirement, whereas preparations with $14 \%$ and $16 \%$ of PVA did not met the requirement after the cycling test and after testing antioxidant effectiveness using the DPPH (1,1-diphenyl-2-pikrilhidrazil) method were obtained. The value of $I C_{50}$ before cycling test was $179.120 \mathrm{mg} / \mathrm{L}$ and after cycling test was $504.74 \mathrm{mg} / \mathrm{L}$. Based on the results of the study it can be concluded that the ethanol extract of Sesewanua leaves can be formulated into a peel-off mask with $12 \%$ PVA concentration which is physically stable and has moderate antioxidant effectiveness before the cycling test, while after cycling test the preparation of peel-off mask ethanol extract of Sesewanua leaves is less effective as an antioxidant.
\end{abstract}

Keywords: Sesewanua leaves (Cleodendron squamatum Vahl.), peel-off mask, antioxidants

\begin{abstract}
ABSTRAK
Daun Sesewanua (Cleodendron squamatum Vahl.) mengandung alkaloid dan flavonoid yang berkhasiat sebagai antioksidan. Penelitian ini bertujuan untuk memformulasi, mengevaluasi, serta menguji efektivitas antioksidan sediaan masker peel-off ekstrak etanol daun Sesewanua. Penelitian ini menggunakan metode deskriptif-analitik dengan perlakuan variasi konsentrasi PVA 12\%, 14\% dan 16\%. Evaluasi fisik sediaan meliputi pengamatan organoleptik, uji homogenitas, uji $\mathrm{pH}$, uji daya sebar, uji waktu mengering dan uji cycling test semua pengujian dilakukan sebelum dan sesudah uji cycling test. Hasil penelitian menunjukkan bahwa semua sediaan memenuhi persyaratan evaluasi fisik sebelum uji cycling test sedangkan setelah uji cycling test hanya sediaan dengan konsentrasi PVA 12\% yang memenuhi persyaratan sedangkan sediaan dengan konsentrasi PVA 14\% dan 16\% tidak memenuhi persyaratan setelah uji cycling test, dan setelah dilakukan uji efektivitas antioksidan dengan metode DPPH (1,1-difenil-2-pikrilhidrazil) diperoleh nilai $\mathrm{IC}_{50}$ sebelum uji cycling test sebesar 179,120 mg/L dan sesudah cycling test sebesar 504,74 mg/L. Berdasarkan hasil penelitian dapat disimpulkan bahwa ekstrak etanol daun Sesewanua dapat diformulasi menjadi sediaan masker peel-off dengan konsentrasi PVA $12 \%$ yang stabil secara fisik dan memiliki efektivitas antioksidan yang sedang sebelum uji cycling test sedangkan setelah cycling test sediaan masker peel-off ektrak etanol daun sesewanua kurang efektif sebagai antioksidan.
\end{abstract}

Kata Kunci : Sesewanua (Cleodendron squamatum Vahl.), masker peel-off, Antioksidan. 


\section{PENDAHULUAN}

Radikal bebas dapat menyebabkan kerusakan oksidatif pada sel-sel kulit sehingga menyebabkan penuaan. Penuaan pada kulit dapat ditandai dengan munculnya keriput, pecah-pecah, tampak kusam, kering, kulit menjadi cepat tua dan muncul flek-flek hitam (Maysuhara, 2009).

Antioksidan merupakan senyawa yang dapat menangkal efek buruk dari radikal bebas. Salah satu tanaman yang memiliki kandungan antioksidan ialah Sesewanua (Cleodendron squamatum Vahl.). Menurut Sangi et al. (2008) alkaloid dan flavonoid yang merupakan senyawa yang berpotensi sebagai antioksidan.

Efek antioksidan akan lebih baik bila diformulasikan dalam bentuk sediaan topikal seperti kosmetik dibandingkan oral, karena zat aktif dapat lebih lama berinteraksi dengan kulit wajah (Draelos, 2006).

Salah satu bentuk sediaan topikal yang telah dikembangkan ialah masker peel-off. Masker peel-off merupakan masker yang berbentuk gel yang diaplikasikan ke kulit dan dalam waktu tertentu akan membentuk lapisan film transparan yang elastis, setelah kering masker dapat langsung diangkat tanpa perlu dibilas. Masker peel-off tersusun dari polivinil alkohol (PVA) yang digunakan sebagai pembentuk film, PVA merupakan bahan yang sangat penting dalam formulasi sediaan masker peel-off, karena PVA merupakan salah satu polimer yang dapat memberikan efek peel-off pada masker (Wasitaatmadja, 1997).

\section{METODOLOGI PENELITIAN}

\section{Waktu dan Tempat Penelitian}

Penelitian ini dilakukan pada bulan Oktober 2018 - Februari 2019, di Laboratorium
Teknologi Farmasi, Program studi Farmasi, Fakultas Matematika dan Ilmu Pengetahuan Alam, Universitas Sam Ratulangi Manado.

\begin{abstract}
Alat
Alat yang digunakan dalam penelitian ini ialah blender (Philips), ayakan, kertas saring, pipet tetes, sudip, $\mathrm{pH}$ Universal, stopwatch, oven (Ecocell MMM Group), lemari pendingin, mixer (Philips), pipet mikro $\left(\right.$ ecopippette $\left.^{\mathrm{TM}}\right)$, vortex (Mixer Hwashin ${ }^{\circledR}$ ), timbangan analitik (Ae Adam ${ }^{\circledR}$ ), penangas (Nesco $\left.{ }^{\circledR} \mathrm{Lab}\right)$, pemberat, lumpang dan alu, kertas label, aluminium foil, Spektrofotometer (Shimadzu UV-1800) dan alat-alat gelas yang biasa digunakan di laboratorium.
\end{abstract}

\section{Bahan}

penelitian ini yaitu daun Sesewanua (Cleodendron squamatum Vahl.), Polivinil Alkohol (PVA), Hidroksipropil Metilselulosa (HPMC), Propilen glikol, Metil Paraben, Etanol 96\%, Aquadest, DPPH (1,1-difenil-2pikrilhidrazil), Metanol p.a, Etanol p.a.

\section{Metode Penelitian}

Penelitian ini menggunakan metode deskriptif-analitik dengan perlakuan variasi konsentrasi PVA 12\%, 14\% dan 16\%.

\section{Prosedur Penelitian}

Pengambilan Sampel

Sampel diambil di Kelurahan Tondangow, Kecamatan Tomohon Selatan, Kota Tomohon. Bahan yang digunakan ialah bagian daun Sesewanua.

\section{Identifikasi Tanaman}

Identifikasi tanaman dilakukan di Laboratorium Taksonomi Tumbuhan, Jurusan 
Biologi, Fakultas Matematika dan Ilmu Pengetahuan Alam, Universitas Sam Ratulangi Manado.

\section{Preparasi Sampel}

Daun Sesewanua dicuci dengan air mengalir untuk menghilangkan kotoran yang menempel, selanjutnya dirajang menjadi potongan-potongan kecil, dan dikeringkan dengan cara diangin-anginkan. Sampel kering kemudian dihaluskan dengan menggunakan blender. Serbuk sampel daun Sesewanua diayak dengan ayakan untuk mendapatkan serbuk yang halus.

\section{Pembuatan Ekstrak}

Ekstraksi daun Sesewanua dilakukan dengan metode maserasi menggunakan etanol $96 \%$, ekstraksi dilakukan selama 3x24 jam disertai pengadukan. Setiap 24 jam ekstrak disaring kemudian di remaserasi kembali dengan pelarut yang baru selama $2 \times 24$ jam. Filtrat kemudian dioven (suhu $40^{\circ} \mathrm{C}$ ) hingga diperoleh ekstrak kental.

\section{Formulasi Sediaan Masker peel-off}

Formulasi Sediaan Masker peel-off ekstrak etanol daun Sesewanua dengan variasi PVA dapat dilihat pada Tabel. 1

\begin{tabular}{|c|c|c|c|c|c|c|c|c|c|}
\hline \multirow{2}{*}{ Bahan } & \multirow{2}{*}{ Fungsi } & \multicolumn{8}{|c|}{ Konsentrasi $\%$ b/v } \\
\hline & & Fo & & $\mathrm{Fl}$ & & F2 & & F3 & \\
\hline Ektrak & Bahan & - & & 1 & & 1 & & 1 & \\
\hline Sesewantua & Aktif & & & & & & & & \\
\hline PVA & Plasticiecr & 10 & & 12 & & 14 & & 16 & \\
\hline HPMC & $\begin{array}{l}\text { Peringkat } \\
\text { Viskositas }\end{array}$ & 2 & & 2 & & 2 & & 2 & \\
\hline Propilenglikol & Humcktan & 14 & & 14 & & 14 & & 14 & \\
\hline Metil Paraben & Pengawet & 0,05 & & 0,05 & & 0,05 & & 0,05 & \\
\hline Etanol $96 \%$ & Pelanut & 8 & & 8 & & 8 & & 8 & \\
\hline Aquadest & Pelanut & $\begin{array}{l}\text { Ad } \\
\text { mi }\end{array}$ & 100 & $\begin{array}{l}\text { Ad } \\
\text { int. }\end{array}$ & 100 & $\begin{array}{l}\text { Ad } \\
\text { mL. }\end{array}$ & 100 & $\begin{array}{l}\text { Ad } \\
\text { mi. }\end{array}$ & 100 \\
\hline
\end{tabular}

\section{Sediaan Masker Peel-off}

Pembuatan sediaan masker wajah peeloff dimulai dengan melarutkan ekstrak daun Sesewanua dalam etanol $96 \%$ sedikit-sedikit sehingga ekstrak daun Sesewanua terdispersi. Kemudian di wadah terpisah, Polivinil alkohol (PVA) dikembangkan ke dalam aquades hangat (suhu $80^{\circ} \mathrm{C}$ ) diaduk hingga mengembang sempurna. Setelah itu, PVA yang telah mengembang dihomogenkan (Wadah 1). Selanjutnya HPMC dikembangkan dalam aquades dingin dengan pengadukan yang konstan hingga HPMC mengembang sempurna (Wadah 2). Pada wadah terpisah lainnya (Wadah 3), Metil paraben dilarutkan dalam propilen glikol. Kemudian Wadah 2 dan Wadah 3 dicampurkan secara berturut-turut pada wadah 1, dilakukan pengadukan sampai semua bahan tercampur dan tampak homogen. Setelah itu, ekstrak yang telah dilarutkan dalam $96 \%$ etanol ditambahkan sedikit demi sedikit, lalu diaduk sampai homogen, kemudian ditambahkan aquades hingga $100 \mathrm{~mL}$ dan aduk kembali hingga homogen.

\section{Evaluasi Fisik Sediaan Masker Peel-off Pengamatan Organoleptik}

Sediaan masker gel peel-off yang telah dibuat kemudian diamati, pengamatan ini meliputi pengamatan terhadap warna, bau serta kejernihan dari sediaan masker gel peel-off (Septiani, 2011).

\section{Uji Homogenitas}

Pengujian homogenitas dilakukan dengan cara mengoleskan sampel sediaan masker peeloff diatas kaca objek, kemudian kaca objek tersebut dikatupkan dengan kaca objek lainnya dan dilihat apakah gel tersebut homogen atau tidak (Kuncari, 2014). 


\section{Pengujian pH}

Sediaan masker peel-off yang akan diuji disiapkan sebanyak $1 \mathrm{~g}$ dilarutkan dengan 10 $\mathrm{mL}$ aquadest (10\%). Selanjutnya, $\mathrm{pH}$ sediaan diamati berdasarkan perubahan warna pada kertas pH (Froelich, dkk., 2017).

\section{Uji daya sebar}

Sebanyak $1 \mathrm{~g}$ sediaan masker peel-off ditimbang kemudian diletakkan diatas kaca, selanjutnya ditutup dengan kaca lain dan diberikan pemberat $150 \mathrm{~g}$, setelah 1 menit, kemudian diameter yang terbentuk diukur (Froelich, dkk., 2017).

\section{Uji waktu mengering}

Sebanyak 0,5 gram sediaan masker gel peel-off dioleskan pada kaca objek dengan ketebalan kira-kira $1 \mathrm{~mm}$, kemudian dimasukkan ke dalam oven pada temperature $37^{\circ} \mathrm{C}$, waktu sediaan mengering dihitung dengan menggunakan stopwatch. (Priani et al 2015).

\section{Uji Cycling test}

Sediaan disimpan pada suhu $4^{\circ} \mathrm{C}$ selama 24 jam kemudian dipindahkan pada suhu $40^{\circ} \mathrm{C}$ selama 24 jam dilakukan 6 siklus dan diamati terjadinya perubahan fisika dari sediaan (Rieger, 2000).

\section{Uji Efektivitas Antioksidan}

Uji efektivitas antioksidan dilakukan pada sediaan yang menunjukan kestabilan terbaik sebelum dan sesudah cycling test. Sebanyak $2 \mathrm{~mL}$ sampel dengan konsentrasi 50 ppm, 100 ppm, 150 ppm, 200 ppm dan 250 ppm masing-masing ditambahkan $2 \mathrm{~mL}$ larutan DPPH (1,1-difenil-2-pikrilhidrazil) 40 ppm dan divortex selama 2 menit, kemudian diinkubasi dalam ruangan gelap selama 30 menit. Selanjutnya, absorbansi sampel diukur pada $\lambda$
$517 \mathrm{~nm}$ dengan menggunakan Spektrofotometer UV-Vis. Absorbansi masing-masing sampel dicatat, untuk selanjutnya akan dihitung aktivitas penangkal radikal bebas dan nilai $\mathrm{IC}_{50}$ dari sampel.

\section{HASIL DAN PEMBAHASAN}

Penelitian ini bertujuan untuk memformulasi ekstrak etanol daun Sesewanua dalam bentuk sediaan kosmetika yaitu masker peel-off. Daun Sesewanua dipilih karena menurut penelitian yang dilakukan Huliselan (2015), Ekstrak etanol daun Sesewanua mempunyai aktivitas antioksidan yang sangat kuat dengan nilai $\mathrm{IC}_{50} 17,85 \mathrm{mg} / \mathrm{L}$. Sediaan masker peel-off dipilih karena dinilai lebih efektif dan efisien baik dari segi pemakaian maupun efeknya. Menurut Moris (1993) sediaan dalam bentuk masker peel-off mempunyai konsistensi seperti gel yang mudah untuk diaplikasikan ke kulit, dengan cara dioleskan dan dibiarkan hingga mengering dan membentuk lapisan film yang transparan serta mudah untuk dikelupas, sehingga tidak memerlukan proses pencucian seperti masker bentuk lain pada umumnya.

Uji organoleptik bertujuan untuk mengamati bentuk, warna dan bau dari sediaan masker peel-off, secara organoleptis sediaan F1, F2, dan F3 yang mengandung ekstrak, berwarna hijau pekat, sedangkan sediaan masker peel-off yang tidak mengandung ekstrak daun Sesewanua F0 terlihat jernih (tidak berwarna). Sediaan F0 yang dihasilkan berbau etanol karena adanya kandungan etanol dalam formula, namun untuk sediaan F1, F2, dan F3 mempunyai aroma khas ekstrak Sesewanua serta berbentuk setengah padat. Setelah dilakukan uji cycling test uji organoleptik tidak ditemukan adanya perbedaan yang signifikan untuk masing-masing sediaan namun F0 bau 
khas etanol semakin berkurang dan untuk F1, F2, dan F3 bau khas ekstrak Sesewanua semakin mendominasi. Warna masing-masing sediaan tidak mengalami perubahan. dan bentuk setengah padat.

Seperti pada penelitian yang dilakukan Luther (2016) formula gel masker peel-off yang tidak mengandung ekstrak, bau etanol berkurang untuk masing-masing sediaan, menurut Septiani (2011) hal ini dikarenakan pengaruh suhu saat cycling test, mengakibatkan etanol yang terkandung dalam sediaan menguap sehingga aroma yang lebih dominan ialah aroma dari ekstrak yang digunakan. Penguapan etanol pada sediaan dapat pula disebabkan karena pemilihan wadah yang kurang sesuai serta kontak dengan lingkungan yang terlalu lama sehingga menyebabkan terjadinya penguapan etanol, karena etanol memiliki sifat yang mudah menguap.

Uji homogenitas dilakukan untuk melihat ada tidaknya partikel kasar pada sediaan. Dari keempat sediaan F0, F1, F2 dan F3 yang diamati memiliki homogenitas yang baik karena tidak ditemukannya partikel kasar dalam sediaan. Setelah uji cycling test tidak ditemukannya partikel kasar dalam sediaan sehingga sediaan masih dapat dikatakan stabil dan menunjukan bahwa bahan-bahan yang terkandung di dalamnya tercampur dengan baik (Fitriana, 2012).

Uji pH dilakukan untuk mengetahui nilai $\mathrm{pH}$ dari sediaan apakah sesuai atau tidak, masker peel-off merupakan sediaan yang pengaplikasiannya pada kulit wajah sehingga nilai $\mathrm{pH}$ sediaan harus sesuai dengan $\mathrm{pH}$ kulit wajah yaitu 4,5-6,5. Karena apabila nilai $\mathrm{pH}$ suatu sediaan terlalu asam < 4,5 akan menyebabkan kulit iritasi, sedangkan apabila nilai $\mathrm{pH}$ suatu sediaan $>6,5$ atau terlalu basa dapat menyebabkan kulit bersisik (Rahmawaty, dkk., 2015). Dalam penelitian ini keempat sediaan F0, F1, F2, F3 memiliki nilai pH yang baik karena masih berada dalam range 4,5-6,5 yaitu 5 untuk F1, F2, F3, dan 6 untuk nilai pH F0, walaupun memiliki nilai $\mathrm{pH}$ yang lebih tinggi dari ketiga sediaan lainnya namun masih dalam batas yang diperbolehkan. Perbedaan ini disebabkan karena penambahan ekstrak Sesewanua dalam sediaan, sediaan yang mengandung ekstrak daun Sesewanua memiliki pH yang lebih asam dibandingkan dengan sediaan tanpa ekstrak, hal ini disebabkan kandungan flavonoid yang bersifat asam (Markham, 1998). Setelah dilakukan uji cycling test $\mathrm{pH}$ masing-masing sediaan diukur dengan kertas $\mathrm{pH}$ universal dan menunjukan terjadinya kenaikan $\mathrm{pH}$ yang awalnya $\mathrm{pH}$ sediaan untuk basis adalah 6 setelah dilakukan uji cycling test $\mathrm{pH}$ basis menjadi 7 begitupun dengan ketiga sediaan lain awalnya $\mathrm{pH}$ yang diperoleh masing-masing sediaan adalah 5 setelah uji cycling test $\mathrm{pH}$ masing-masing sediaan adalah 6. Menurut Young et al., (2002) perubahan $\mathrm{pH}$ pada sediaan dapat dipengaruhi oleh media yang terdekomposisi pada suhu tinggi saat pembuatan ataupun penyimpanan yang menghasilkan asam atau basa, $\mathrm{pH}$ dipengaruhi oleh faktor lingkungan seperti suhu serta penyimpanan yang kurang baik.

Uji daya sebar dimaksudkan untuk mengetahui kemampuan menyebar dari sediaan, daya sebar sediaan masker peel-off dikatakan baik yaitu antara $5-7 \mathrm{~cm}$. Menurut Voight (1994), daya sebar yang baik mempengaruhi pelepasan zat aktif yang memuaskan. Hasil uji daya sebar sebelum cycling-test untuk F0, F1, F2 dan F3 berada pada rentang 5,53-7,3 cm yang menunjukan daya sebar yang baik, semakin besar daya sebar yang diperoleh menunjukan semakin cepat pula zat aktif dalam sediaan dapat menyebar di permukaan kulit 
(Voight, 1994). Selain itu, daya sebar sediaan juga dipengaruhi oleh penggunaan PVA, peningkatan penggunaan PVA akan menyebabkan daya menyebar sediaan semakin berkurang. Penurunan daya sebar terjadi melalui peningkatan ukuran unit molekul karena telah mengabsorbsi pelarut sehingga terjadi peningkatan tahanan untuk mengalir (viskositas) yang mempengaruhi kemampuan menyebar (Martin et al., 1993). Sediaan F3 dengan konsentrasi PVA paling tinggi yakni $16 \%$ memiliki kemampuan penyebaran yang rendah. Seperti penelitian yang dilakukan Anggraeni (2018) yang menggunakan variasi konsentrasi PVA 10, 12, dan 13\% dimana pengujian daya sebar yang diperoleh menunjukan penurunan daya sebar seiring dengan peningkatan penggunaan PVA untuk konsentrasi $13 \%$ menunjukkan daya sebar terendah $4,71 \mathrm{~cm}$ sedangkan untuk konsentrasi $10 \%$ daya sebarnya $5,49 \mathrm{~cm}$, peningkatan kemampuan menyebar sediaan juga dipengaruhi oleh viskositas sediaan, semakin besar viskositas suatu sediaan maka penyebarannya semakin kecil, dalam penelitian tersebut viskositas sediaan dengan PVA 10\% ialah $2.400 \mathrm{cps}$, dan viskositas untuk sediaan dengan PVA 13\% $3.833 \mathrm{cps}$, dalam penelitian ini tidak dilakukan pengujian viskositas namun berdasarkan pengamatan yang dilakukan terjadi peningkatan viskositas dari sediaan yang telah dilakukan dilihat dengan semakin kentalnya sediaan setelah cycling test. Daya sebar setelah dilakukannya cycling test berada pada rentang 4,63-6,5 cm untuk F0 dan F1 berada pada standar daya sebar yang baik, sedangkan untuk F2 dan F3 menunjukan daya sebar yang kurang baik < $5 \mathrm{~cm}$, menurut Beringhs et al., (2013) hal ini disebabkan karena pengaruh suhu saat uji cycling test yang menyebabkan menguapnya etanol serta dipengaruhi konsentrasi PVA dalam sediaan sehingga daya sebar yang dihasilkan semakin kecil. Uji waktu mengering bertujuan untuk mengetahui waktu yang dibutuhkan sediaan untuk mengering. Waktu mengering sediaan masker peel-off yang baik yaitu antara 15-30 menit (Vieira, 2009). Dalam penelitian ini waktu mengering sediaan dilakukan sebelum dan sesudah cycling test, sebelum dilakukan cycling test waktu sediaan mengering yaitu 24-28 menit dan dikategorikan baik. Uji kecepatan mengering setelah cycling test menunjukan bahwa waktu yang diperlukan sediaan untuk mengering menjadi lebih lama dibandingkan sebelum dilakukan uji cycling test. Menurut Beringhs et al., (2013) penguapan etanol merupakan faktor utama penyebab perpanjangan waktu mengering sediaan karena sifat volatilitas etanol lebih besar daripada air murni sehingga penguapan atau menurunnya konsentrasi etanol dalam sediaan juga mempengaruhi waktu kering sediaan masker peel-off selain itu, menurut Sukmawati (2013) peningkatan konsentrasi PVA juga meningkatkan waktu pengeringan sediaan, semakin besar konsentrasi PVA yang digunakan menyebabkan semakin cepat pula waktu mengering sediaan, karena banyaknya kandungan air pada setiap formula dapat memperpanjang waktu mengering dalam sediaan. Dalam penelitian ini hasil yang diperoleh untuk F1, F2, dan F3 masih pada rentang waktu sesuai persyaratan yaitu berturutturut 29,02 menit, 28,36 menit, dan 28,02 menit. Sedangkan untuk F0 waktu sediaan mengering lebih lama yaitu 31,2 menit dan sudah tidak memenuhi syarat waktu mengering sediaan masker peel-off yang seharusnya berkisar antara 15-30 menit.

Uji efektivitas antioksidan sediaan masker peel-off dilakukan pada sediaan masker peel-off dengan konsentrasi PVA $12 \%$ atau 
pada F1 sebelum dan sesudah cycling test untuk melihat apakah ada aktivitas antioksidan dari sediaan serta untuk melihat pengaruh uji cycling test terhadap efektivitas antioksidan dari sediaan, pengujian antioksidan dilakukan dengan metode DPPH (1,1-difenil-2pikrilhidrazil). Metode peredaman radikal bebas menggunakan DPPH ini didasarkan pada reduksi dari larutan methanol radikal bebas DPPH yang berubah warna oleh penghambatan radikal bebas. Dalam penelitian ini setelah larutan ekstrak direaksikan dengan larutan DPPH selama 30 menit, menghasilkan warna ungu DPPH yang memudar, hal tersebut Tabel 2. Hasil pengujian efektivitas antioksidan dikarenakan terjadinya pengaruh penghambatan radikal bebas DPPH oleh sampel sediaan masker peel-off yang ekstrak daun sesewanua yang mengandung flavonoid dan alkaloid. Menurut Sangi et al. (2008) alkaloid dan flavonoid yang terdapat dalam daun Sesewanua merupakan senyawa yang berpotensi sebagai antioksidan. Menurut, Prayoga (2013) Ketika larutan DPPH yang berwarna ungu bertemu dengan bahan pendonor electron atau hidrogen maka DPPH akan tereduksi, menyebabkan warna ungu akan memudar digantikan warna kuning yang berasal dari gugus pikril.

\begin{tabular}{ccccccc}
\hline \multirow{2}{*}{$\begin{array}{c}\text { Konsentrasi } \\
(\mathrm{ppm})\end{array}$} & \multicolumn{2}{c}{ Absorbansi $(\mathrm{nm})$} & \multicolumn{2}{c}{$\%$ Inhibisi } & \multicolumn{2}{c}{$\mathrm{IC}_{50}(\mathrm{mg} / \mathrm{L})$} \\
\cline { 2 - 7 } & Sebelum & Sesudah & Sebelum & Sesudah & Sebelum & Sesudah \\
\hline 50 & 0,59 & 0,76 & 24,64 & 2,93 & & \\
100 & 0,55 & 0,73 & 29,75 & 6,77 & & \\
150 & 0,36 & 0,69 & 38,68 & 11,88 & 179,120 & 504,74 \\
200 & 0,34 & 0,66 & 41,25 & 15,71 & & \\
250 & 0,33 & 0,61 & 54,02 & 22,09 & & \\
\hline
\end{tabular}

Tabel 2. menunjukan semakin besar konsentrasi ekstrak yang ditambahkan maka semakin besar pula aktivitas penghambatan radikal bebas yang ditunjukan, dapat dilihat untuk konsentrasi 250 ppm sebelum cycling test menunjukan aktivitas penghambatan radikal bebas sebesar 54\% sedangkan untuk konsentrasi terendah yaitu 50 ppm penghambatan aktivitas radikal bebas yang diperoleh hanya $24,64 \%$ terdapat perbedaan yang signifikan pada hasil pengujian sediaan masker peel-off sebelum dan sesudah cycling test, dimana untuk penghambatan aktivitas sediaan masker peel-off sesudah cycling test pada konsentrasi $50 \mathrm{ppm}$ hanya menunjukan persentase penghambatan radikal bebas sebesar $2,93 \%$ dan untuk konsentrasi 250 ppm sebesar $22,09 \%$. Setelah dilakukan perhitungan $\mathrm{IC}_{50}$, nilai $\mathrm{IC}_{50}$ untuk sediaan masker peel-off $\mathrm{F} 1$ sebelum cycling test sebesar 179,120 mg/L

dikategorikan antioksidan yang sedang karena nilai $\mathrm{IC}_{50}$ yang diperoleh berada pada rentang 150-200 $\mathrm{mg} / \mathrm{L}$ sedangkan, nilai $\mathrm{IC}_{50}$ untuk sediaan masker peel-off $\mathrm{F} 1$ sesudah cycling test adalah $504,74 \mathrm{mg} / \mathrm{L}$, berada pada rentang 200 $1000 \mathrm{mg} / \mathrm{L}$ yang dinyatakan kurang aktif sebagai antioksidan namun masih memiliki potensi sebagai antioksidan (Molyneux, 2004). Dari hasil tersebut juga dapat disimpulkan bahwa penyimpanan cycling test turut mempengaruhi penurunan aktivitas antioksidan dari sediaan hal tersebut karena perubahan suhu yang mempengaruhi struktur fisika dari sediaan namun juga mempengaruhi struktur kimia sediaan yang berpengaruh pada aktifitas zat aktif yang terkandung di dalamnya (Oslon, 2013). Menurut Henny et al., (2017) hal ini disebabkan karena penyimpanan yang dapat dipengaruhi oleh faktor lingkungan seperti 
cahaya yang dapat menyebabkan proses oksidasi yang dapat menurunkan aktivitas antioksidan, cara pengemasan yang kuran baik juga dapat menyebabkan sediaan lebih banyak mengalami kontak dengan lingkungan, sehingga menurunkan aktivitas antioksidan sediaan

\section{KESIMPULAN}

Ekstrak etanol daun Sesewanua dapat diformulasikan menjadi sediaan masker peeloff. Konsentrasi PVA yang menghasilkan sediaan masker peel-off yang stabil secara fisik ialah konsentrasi 12\%. Hasil uji efektivitas antioksidan sediaan masker peel-off ekstrak etanol daun Sesewanua dengan konsentrsi PVA $12 \%$ sebelum cycling test diperoleh nilai $\mathrm{IC}_{50}$ sebesar 179,120 mg/L yang tergolong sedang dan sesudah cycling test nilai $\mathrm{IC}_{50}$ sebesar $504,74 \mathrm{mg} / \mathrm{L}$, sehingga dapat disimpulkan bahwa sediaan masker peel-off ektrak etanol daun sesewanua kurang efektif sebagai antioksidan sesudah pengujian cycling test.

\section{DAFTAR PUSTAKA}

Anggraeni, 2018. Formulasi Masker Gel Peeloff dari Ekstrak EtanolUmbi Bawang Dayak (Eleutherinebulbosa (Mill.) Urb. Eleutherine Americana Merr).Jurnal Ilmu Farmasi dan Farmasi Klinik.Vol.15, No.1, 01-11

Beringhs AO, Julia MR, Hellen KS, Rosane MB, Diva S. Green clay and aloe vera peel-off facial masks: response surface methodology applied to the formulation design. AAPS Pharm Sci Tech. 2013;14(1):445-455.

Draelos, Z. D., dan Lauren A. Thaman, 2006, Cosmetic Formulation of Skin Care Product, 362, Taylor and Francis Group, New York.

Fitriana, N. 2012. Formulasi Gel Ekstrak Daun Beluntas (Pluceaindica Less) dengan Na-CMC sebagai Basis Gel, Journal of
Pharmaceutical Science and Herbal Technology Vol. 1 No. 1, 41-44.

Froelich, A., Osmalek, T., Snela, A., Kunstman, P., Jadach, B. 2017. Novel microemulsion-based gels for topical delivery of indomethacin: Formulation, physicochemical properties and in vitro drug release studies. Journal of Colloid and Interface Science. 507: 323-336. Garg, A., D. Aggarwal, S. Garg, dan A. K. Sigla. 2002. Spreading of Semisolid Formulation.USA: Pharmaceutical Technology. pp. 84- 104.

Henny, M. 2017. Oxidants, Antioxidants and The Degenerative Diseases of Aging. Proc. Nati. Acid. Sci. USA, 90: 7915-792.

Huliselan, Y. 2015. Aktivitas Antioksidan Ekstrak Etanol, Etil Asetat, dan nHeksan dari daun Sesewanua (Cleodendron squamatum Vahl.)

Kuncari, 2014. Evaluasi, Uji Stabilitas Fisik dan Sinersis Sediaan Gel yang Mengandung Minoksidil, Apigenin dan Perasan Herba Seledri (Apium graveolens L.). Buletin Penelitian Kesehatan. 42(4):213-222.

Luther, P. 2016. Formulasi dan Evaluasi Fisik Masker Peel-off yang mengandung Ekstrak Etanol 96\% Kulit Batang Nangka (Atrocarpus heterophyllus Lamk.) Asam Glikolat dan Niasinamida.UIN: Jakarta.

Markham, K.R., 1988, Cara Mengidentifikasi Flavonoid, diterjemahkan oleh Kosasih Padmawinata, 15, Penerbit ITB, Bandung.

Martin, A., J, Swarbrick., and A., Cammarata. 1993. Farmasi Fisik:Dasar-dasar Farmasi Fisik dalam Ilmu Farmasetik.Edisi Ketiga. Penerjemah: Yoshita. Jakarta: UI Press.

Maysuhara, S. 2009. Rahasia Cantik, Sehat dan Awet Muda.Yogyakarta: Pustaka Panasea.

Molyneux P. 2004. The use of the stable free radical dipHenylpicrylhydrazyl (DPPH) for estimating antioxidant 
activity. J. Sci. Technol.26(2):211219.

Morris, K. 1993. Depilatories Mask Scrubs and Bleaching Preparation, Paucher's Perfumes Cosmetics and Soaps. Chapman and Hall: London.

Oslon, J,. N. 2013. Penapisan Aktivitas Antioksidan dan beberapa tumbuhan Obat Indonesia Menggunakan radikal 2,2-Diphenyl-1 Picrylhydrazyl (DPPH). Majalah Obat Tradisional. 16 (1): 22-25.

Prayoga, H. 2013 Antioxidant analysis of different parts of Carica papaya. International Food Research Journal. 20 (3):1043-1048.

Priani SE, Yani L, Nabila.2013. Formulasi mikroemulsi fraksi etil asetat kulitbuah manggis. Jurnal Bahans Alam Indonesia.8(6).

Rahmawanty, Dina., Nita. Yulianti, dan Mia. Fitriana. 2015. Formulasi danEvaluasi Masker Wajah Peel-off Mengandung Kuersetin Dengan Variasi Konsentrasi Gelatin dan Gliserin."Media Farmasi. 12 (1): 17-32. Research. (5): 33-336.

Rieger, M. M. 2000. Harry's Cosmetology $8^{\text {th }}$ edition. Chemical Publishing Co. Inc., New York: 20-36, 118, 247-251, 359, 428.

Sangi, M., Runtuwene, M.R.J., Simbala, H.E.I., Makang, V.M.A. 2008. Analisis Fitokimia Tumbuhan Obat di Kabupaten Minahasa Utara. Chemistry Progress. 1: 47-53.

Septiani, Shanti, Nasrul Wathoni, and Soraya R. Mita. 2012. Formulasi Sediaan. Masker Gel Antioksidan Dari Ekstrak
Etanol Biji Melinjo (GnetungnemonLinn.). Students $e$ Journals.1-27 Masker Gel Antioksidan Dari Ekstrak Etanol Biji Melinjo (Gnetun gnemon Linn.). Students e- Journals.1-27

Sie, J. O. 2013. Daya Antioksidan Ekstrak Etanol Kulit Buah Manggis (Garcinia Mangostana Linn.) Hasil Pengadukan dan Reflux. Calyptra. 2: 1-10.

Singh, G., Kapoor, I. P. S., Singh, O., Heluani, C, S., Lampasona, M. P., \& Catalan, C, A, N., 2004, Chemistry, Antioxidant, and Antimicrobial investigations on essential oil and oleoresin of Zingeber officinale, Food and Chemical Toxicology 46, 32593302.

Sukmawati J. 2013. Application and Stability Evaluation of Polymer blends in Cosmetics. International Journal for Research in Applied Science \& Engineering

Vieira R.P. 2009.PHysical and physicochemical stability evaluation of cosmetic formulations containing soybean extract fermented by bifidobacterium animalis. Brazilian.

Voight, R., 1994, Buku Pengantar Teknologi Farmasi, 572-574, diterjemahkan oleh Seodani, N., Edisi V, Yogyakarta, Universitas Gajah Mada Press

Wasitaatmadja, S.M. 1997. Penuntun Ilmu Kosmetik Medik, Universitas Indonesia, Jakarta.

Young, B. Anne. 2002. Practical Cosmetic Science. 39-40, Mills and Boon Limited, London 